\title{
ILMU DASAR ALGORITMA DAN PEMROGRAMAN
}

\author{
Oleh : Nabila sari hasibuan \\ Pendidikan Matematika FITK UIN Sumatera Utara \\ nabilasarihsb00@gmail.com
}

\begin{abstract}
ABSTRAK
Algoritma merupakan deretan instruksi yang jelas serta tidak ambigu untuk membongkar permasalahan komputasi, wajib bisa membagikan luaran yang di idamkan dari sesuatu masukkan dalam jumlah waktu yang terbatas. Algoritma yang ditulis dalam bahasa pc dinamakan program. Supaya bisa diseksekusi oleh pc, algoritma wajib dikonversi ke dalam bahasa program. Bahasa yang digunakan buat menulis program dinamakan bahasa pemrograman. Orang yang membuat program pc diucap pemrogram, serta aktivitas merancang serta menulis program diucap pemrograman, dan terdapat kegiatan menulis kode program dinamakan coding. Terdapat 3 metode dalam menyusun algoritma ialah: (1) Deskriptif, (2) Pseudocode, serta (3) Flowchart. Berikut ini hendak dipaparkan tentang penafsiran serta perbandingan Algoritma serta Pemrograman. Sehabis membaca postingan ini, diharapkan kamu bisa paham tentang: 1.) Ikatan Algoritma serta Pemrograman. 2.) Perbandingan Algoritma serta Pemrograman dan 3.) Kenapa Algoritma butuh dipelajari oleh pakar pada bidang non IT.
\end{abstract}

Kata Kunci : Algoritma, Pemrograman, Deskriptif, Pseudocode, Flowchart.

\section{Pendahuluan}

Seiring dengan perkembangan IT yang semakin pesat juga berdampak di berbagai bidang ilmu. Dengan pesatnya berbagai bidang ilmu tersebut, aplikasi matematika sebagai pendukung bidang ilmu lain juga mengalami perkembangan, misalnya pemrograman. (Franita, 2019)

Dalam pemrograman, penting untuk menguasai logika berpikir tentang bagaimana menyelesaikan masalah pemrograman yang akan dimunculkan. Terkadang muncul masalah matematika yang sangat mudah untuk dikerjakan secara tertulis, namun dalam pemrograman sangat sulit untuk dilaksanakan. Jika dihadapkan dengan ini, maka algoritma dan logika pemrograman sangat penting untuk menyelesaikan masalah. (Ritayani)

Algoritma itu berbeda dengan pelajaran logaritma. Logaritma adalah suatu invers atau kebalikan dari eksponen atau pemangkatan. (Maulana, 2017)

Dilihat dari asal katanya, "algoritma" sendiri memiliki sejarah yang lumayan aneh. Satu-satunya kata yang ditemukan algorism ialah proses penghitungan menggunakan angka Arab. Ahli bahasa mencoba 
menciptakan asal kata algorism tetapi tidak mendapatkan hasil yang sesuai. Akhirnya, sejarawan matematika menciptakan asal kata algorism tersebut, yaitu berasal dari nama penulis kitab yang terkenal, tidak lain lagi namanya Abu Ja'far Muhammad ibnu Musa al-Khuwarizmi (Orang barat menyebut alkhwarizmi dengan sebutan algorism.). Buku yang bertajuk Kitab al jabar wal muqabala yang artinya "buku pemugaran dan pengurangan", Pergantian kata algorism jadi algoritm berasal dari kata algorism yang sering digabungkan dengan arithmetics, sehingga akhiran -sm telah berubah menjadi perihal biasa, karena kata algorithm lambat laun digunakan sebagai metode komputasi secara universal. Menyebabkan kehilangan makna aslinya. Sebaliknya kata algorithm dalam bahasa Indonesia diserap sebagai "algoritma". (Sari, 2020)

Algoritma merupakan suatu sebutan yang mengganti ketentuan yang terdapat pada aritmetis yang bermanfaat buat menyelesaikan permasalahan dengan memakai bilangan angka Arab. Sebaliknya Algoritma Pemrograman merupakan langkah- langkah yang disusun secara tertib buat menuntaskan sesuatu permasalahan pemrograman pc. Permasalahan yang hendak dipindahkan oleh pc pertama dicoba formulasi langkah-langkah penyelesaian sesuatu permasalahan dengan pc yang hendak melaksanakan instruksi-instruksi tersebut. Agar pc bekerja dengan program itu dikirim ke bahasa yang dimengerti oleh pc, bahasa tersebut merupakan bahasa pemrograman. BASIC, PASCAL, FORTRAN, COBOL, C/ $\mathrm{C}++/ \mathrm{C} \#$ ialah bahasa pemrograman yang kerap diketahui. Bahasa pemrograman bisa dipecah jadi 2 kelompok, ialah kelompok awal merupakan bahasa pemrograman bertujuan khusus seperti cobol, fortran, bahasa rakitan, prolog, bahasa-bahasa simulasi, serta sebagainya. Kelompok kedua adalah bahasa perograman bertujuan universal, bahasa perograman ini bisa digunakan buat bermacam aplikasi. Contoh dari kelompok kedua merupakan Bahasa Pascal, Basic serta C.( Putriyani)

Niklaus Wirth (1997) melaporkan kalau: Program adalah persatuan algoritma dengan bahasa pemroraman (programming language). Algoritma serta programming language memiliki ikatan yang sangat erat pada suatu program. Algoritma yang kurang baik namun dengan pemilihan struktur informasi yang pas bisa membuat program jadi baik, begitu pula kebalikannya. Algoritma terbuat buat menolong kita dalam mengkonversikan sesuatu kasus ke dalam bahasa pemrograman. Ridho (2013:7) berkata kalau algoritma ialah hasil pemikiran konseptual, serta bisa dilaksanakan oleh pc, algoritma wajib diterjemahkan ke dalam notasi programming language. Program ialah implementasi teknis algoritma yang ditulis dengan menggunakan programming language tertentu sehingga bisa dikerjakan oleh pc. Programming atau pemrograman merupakan kegiatan yang dilakukan untuk membuat sebuah program. Tiap langkah yang terdapat didalam program diucap suatu instruksi (coding). Jadi, program tersusun atas instruksi. Apabila sesuatu instruksi dilakukan, operasi- operasi yang bersesuaian dengan instruksi tersebut dikerjakan pc. ( Isroqmi, 2017)

Dalam penafsiran, algoritma ialah urutan ataupun langkah-langkah dalam menuntaskan serta mengenali permasalahan yang bertabiat logis serta pula sistimatis. Didalam kehidupan tiap hari, bila kita mengamati, sesungguhnya kita senantiasa melaksanakan kaidah-kaidah algoritma. Contohnya merupakan dikala kita membuat 
pop ice. Belakang bungkus pop ice ada metode menyajikan pop ice dengan benar. Jika metode yang tertulis bukanlah logis kita akan memperoleh hasil yang tentu tidak hendak cocok semacam yang diharapkan. ( Ardiansyah, dkk. 2019)

\section{Metode}

Menurut tim Gunadarma 1988 : Algoritma adalah suatu gabungan yang berbatas melalui arahan yang nyata atau jelas dari instruksi metode pelaksanaan dalam menyelesaikan kejadian tertentu serta di minta bahwa gabungan dapat terlaksana secara mekanik.

Pendapat Barakbah (2013:1) bahwa algoritma sangat erat dengan ilmu, ialah suatu keahlian seseorang berpendapat dengan memerlukan daya pikir mengenai suatu kejadian. Manusia yang ahli dengan ilmu yang baik termasuk manusia yang berbudi pekerti yang baik. Dalam menangani suatu kasus atau kejadian sangat memerlukan akal sehat yang baik. (Retta, dkk. 2017)

Algoritma adalah tahapan yang tersusun tercantum dalam pengaturan untuk menangani suatu kasus. Sedangkan algoritma pemrograman adalah tahapan yang dilaksanakan tercantum secara kronologis untuk mengatur suatu kejadian yang berada di komputer. (Syamsudin, 2020)

Pendapat Rinaldi Munir yang terdapat di dalam bukunya yaitu "Algoritma dan Pemrograman dalam Bahasa Pascal dan C" dimana, algoritma ialah susunan dari tahapan yang bertujuan untuk menyelesaikan suatu kasus.

Program melambangkan metode yang berawal dari suatu algoritma yang berbentuk bahasa pemrograman, kemudian bersedia untuk dipraktikkan dalam mesin yang ada di komputer. Mewujudkan program itu ibarat menginformasikan apa yang seharusnya dilaksanakan terhadap orang lain. Seperti contohnya suatu ketika kita menginformasikan algoritma menunjukkan kandidat peserta didik terhadap orang lain, kita sudah pernah melaksanakan pemrograman. (Sari, 2020)

Metode yang digunakan dalam penyusunan artikel adalah deskriptif, dimana penulis menganalisis, menggambarkan dan merangkum kondisi yang berbeda, situasi dari data yang berbeda dikumpulkan. Proses penelitian dilakukan dengan cara megumpulkan data dari berbagai sumber melalui teknik pengumpulan data library research baik dari jurnal, buku maupun portal media yang kredibel dijadikan rujukan berkenaan dengan tema yang dibahas yaitu teori atau konsep algoritma pemrograman, serta analisis untuk memperoleh suatu keterangan atau data yang lebih akurat dan benar.

Pemecahan masalah adalah proses dari masalah hingga pembentukan algoritma. Untuk mendapatkan hasil pemograman yang membantu menyelesaiakan suatu masalah harus dapat melalui tiga tahapan utama, dapat dengan mudah memahami suatu masalah, dan memahami tujuan dibuatnya program. Selain pemahaman, juga penting untuk dapat merumuskan konsep atau desain dan menyelesaikan desain dari masalah yang akan dipecahkan. Akhirnya, hasil desain dapat diterapkan pada program yang disusun secara logis.

- Berlatih memahami dan mengamati masalah sesering mungkin untuk memahami masalah. 
- Setelah melihat suatu masalah, hasil pengamatan tersebut dituangkan kedalam bentuk proses pemecahan masalah, yang disebut dengan algoritma.

- Gunakan bahasa pemograman untuk menerapkannya ke komputer dengan menulis program.

Proses pelaksanaan algoritma sampai menciptakan pemecahan diucap dengan sesi implementasi. Pemecahan yang diartikan yakni sesuatu program yang ialah implementasi dari algoritma yang disusun.

\section{Hasil dan Pembahasan}

\section{Mekanisme Pelaksanaan Algoritma}

Metode supaya algoritma bisa dilaksanakan dalam pc hingga algoritma tersebut wajib di ganti ke notasi programming language. Program yang terbuat dijadikan kedalam salah satu bahasa pemrograman. Penulis sebuah program disebut sebagai programmer. Instruksi atau pernyataan merupakan langkah-langkah yang ada di dalam program. Jadi program adalah "Sebuah instruksi yang sistematis dan logis untuk menyelesaikan permasalahan dengan menggunakan sintaks tertentu ". (Fathoni 2008)

\section{Sifat-sifat dan Ciri-ciri Algoritma}

Sifat-sifat algoritma :

a. Input / Masukan : Yaitu permasalahan yang dihadapi dan akan dicarikan solusinya. Algoritma memiliki nilai 0 atau lebih masukan $(\geq 0)$.

b. Output / Pengeluaran : Suatu algoritma akan menghasilkan output, dimana nilai output didapat dari nilai input yang diproses melalui algoritma. Hal tersebut terjadi ketika algoritma mengubah kondisi awal menjadi kondisi akhir.

c. Definiteness / Pendefinisan : Instruksi yang dibuat didalam algoritma didefinisika dengan jelas sehingga mudah dilaksanakan oleh pengguna algoritma.

d. Finiteness / Penyelesaian : Algoritma harus berakhir setelah melakukan sejumlah langah proses.

e. Effectiveness / Efektifitas : Algoritma harus efektif, langkah algoritma dikerjakan dalam waktu yang benar. (Putriyani)

Adapun ciri-ciri dari Algoritma yaitu:

a. Algoritma mempunyai suatu logika matematika ataupun cara yang tepat dalam menyelesaikan masalah.

b. Algoritma harus ditulis dengan bahasa standar dengan rapi dan tidak ambigu.

c. Setiap langkah harus jelas dan pasti.

d. Diperbolehkan tanpa ada input, tetapi minimal harus ada satu output.

e. Jumlah langkah harus berhingga atau dengan kata lain harus ada stopping criteria.

f. Urutan langkah-langkah untuk memecahkan masalah adalah urutan langkah logis. (Putriyani)

\section{Struktur Dasar Algoritma}

Algoritma bisa dibangun dari 3 struktur bawah, yaitu:

a. Runtunan (sequence) Suatu runtunan terdiri dari satu ataupun lebih statment. Setiap statment dieksekusi secara berurutan 
(sequentially) sesuai dengan urutannya dalam teks algoritma. Sebuah instruksi dieksekusi setelah instruksi sebelumnya telah dieksekusi. Urutan instruksi membenarkan keadaan akhir dari algoritma.

Berikut ini yakni contoh stuktur bawah runtunan:

Algoritma mempertukarkan isi 2 buah ember, A dan B. Dalam algoritma ini terdapat 3 pernyataan yang dikerjakan satu persatu secara berentetan.

a) Taruh air dari ember $\mathrm{A}$ ke dalam ember $\mathrm{C}$

b) Taruh air dari ember $\mathrm{B}$ ke dalam ember A

c) Taruh air dari ember $\mathrm{C}$ ke dalam ember B

b. Pemilihan (selection)

Ada kalanya sebuah instruksi dieksekusi ketika kondisi tertentu dipadati. Struktur ini digunakan untuk memilih apakah kondisi tertentu terpenuhi sehingga perintah dapat dieksekusi. Pemilihan kondisi adalah proses penentuan langkah selanjutnya berdasarkan proses yang ada.

Penulisan pemilihan secara umum :

if kondisi then $\underline{a k s i}$

Contoh :

if Anto mencetak gol then pelatih akan membelikannya sepatu

Adapun bentuk pemilihan yang lain adalah memilih satu dari dua buah aksi bergantung pada nilai kondisinya.

If kondisi then aksi 1

else aksi 2

Contoh :

If tim futsal menang then mengikuti turnamen nasional

else

\section{latihan lebih giat lagi}

(Anggita, 2020)

c. Pengulangan / Repetition / Looping Bila pada sesuatu dikala kita wajib membuat teks berulang (dilakukan lebih dari 1 kali) dalam suatu algoritma, maka kita dapat menggunakan struktur pengulangan. Struktur ini ialah sesuatu proses melaksanakan perintah yang sama secara kesekian hingga batasan yang sudah didetetapkan.

Misal untuk mencetak kata GOOD MORNING sebanyak 9 kali, maka kita akan menulis algoritmanya seperti berikut :

write (“GOOD MORNING"); write ("GOOD MORNING"); write ("GOOD MORNING"); write ("GOOD MORNING"); write ("GOOD MORNING"); write ("GOOD MORNING"); write ("GOOD MORNING"); write ("GOOD MORNING"); write ("GOOD MORNING");

Perulangan proses dalam bahasa pemrograman disebut loop. Dengan menggunakan loop, proses menampilkan kata "GOOD MORNING” sebanyak 9 kali dapat diterapkan dengan kode yang pendek. (Ritayani)

\section{Teks Algoritma}

Teks algoritma ialah uraian instruksi ataupun step-step dari penyelesaian permasalahan yang disusun secara sistematis. 
Instruksi tersebut tidak mempunyai standar yang baku semacam pada programming language namun step-step yang dimilikinya gampang di paham. Biar bacaan algoritma yang terbuat gampang di pindahkan ke programming language hingga terdapat baiknya step-step dari bacaan algoritma yang terbuat berkoresponden dengan perintahperintah programming language. Bacaan algoritma dibuat dari 3 blok. Setiap bagian dapat diberi komentar untuk memperjelas maksud teks yang dituliskan. Komentar biasanya ditulis menggunakan kurung kurawal. (Budiman 2015)

\section{Bagian Kepala (Header)}

Kepala algoritma merupakan bagian yang terdiri atas nama algoritma serta uraian algoritma (spesifikasi) tentang algoritma tersebut. Nama algoritma hendaknya terbuat dengan pendek, tetapi lumayan menggambarkan apa yang hendak dicoba oleh algoritma tersebut. Dibawah nama algoritma diiringi dengan uraian pendek ataupun inti dari apa yang dilakukan algoritma. Uraian di dasar nama algoritma kerap dinamakan pula spesifikasi algoritma. Algoritma wajib ditulis cocok dengan spesifikasi yang di definisikan. Contoh bagian kepala dapat dilihat semacam dibawah ini (Budiman, 2015)

\begin{tabular}{|c|}
\hline $\begin{array}{l}\text { Algoritma } \\
\text { Keliling_Jajar_Genjang }\end{array}$ \\
\hline 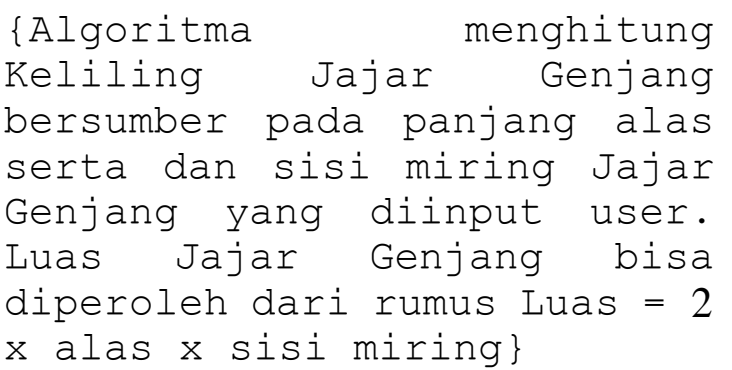 \\
\hline
\end{tabular}

2. Bagian Deklarasi
Didalam algoritma, deklarasi nama merupakan bagian buat mendefenisikan seluruh nama yang dipakai dalam algoritma. Nama tersebut bisa berbentuk nama terapan, nama pergantian, nama jenis, nama prosedur, serta nama guna. Contoh bagian deklarasi bisa dilihat semacam dibawah ini. (Budiman, 2015)

\begin{tabular}{|l|}
\hline DEKLARASI \\
$\begin{array}{l}\text { Panjang }=\text { integer \{tipe data } \\
\text { bilangan bulat\} } \\
\text { Lebar }=\text { integer } \\
\text { Luas = real \{tipe data bilangan } \\
\text { pecahan }\end{array}$ \\
\hline
\end{tabular}

\section{Bagian Deskripsi}

Deskripsi juga merupakan bagian terpenting dari struktur algoritma. Bagian ini berisi uraian langkah-langkah penyelesaian masalah, termasuk beberapa perintah seperti baca data, tampilkan, ulangi, dan sebagainya. Langkah-langkah ini dituliskan dengan notasi yang lazim dalam penulisan algoritma. Setiap langkah algorita dibaca dari langkah paling atas hingga langkah paling bawah. Urutan penulisan menentukan urutan pelaksanaan perintah. Dibawah ini merupakan contoh dari bagian deskripsi algoritma yang mengikuti struktur diatas: (Budiman, 2015)

Deskripsi

Input (panjang, lebar)

Luas $<--$ panjang $\times$ lebar

Output (luas) 


\section{Penyajian Algoritma}

Algoritma pada prinsipnya suatu formula ataupun suatu langkah- langkah kerja. Oleh sebab itu supaya algoritma itu gampang didokumentasikan ataupun gampang buat diajarkan ulang, hingga butuh disajikan dalam wujud tertentu. Penulisan didalam suatu algoritma tidak ada ikatan pada ketentuan tertentu, tetapi wajib jelas iktikad serta tujuan buat masing- masing langkah algoritma tersebut. Pada awalnya algoritma dipecah jadi sebagian berbagai bersumber pada format penulisannya, ialah: (Budiman, 2015)

\section{1) Deskriptif}

Penyajian algoritma dalam bentuk deskriptif maksudnya adalah algoritma yang ditulis dalam bahasa yang dipakai dalam kehidupan sehari-hari (misalnya bahasa Indonesia) dan dalam bentuk kalimat. Setiap langkah algoritma yang dibuat diterangkan dalam satu atau beberapa kalimat. Salah satu contohnya adalah algoritma menentukan bilangan terbesar dari 3 bilangan berikut ini: (Budiman, 2015)

PROGRAM Pengurangan

Diberikan dua buah bilangan bulat a dan $\mathrm{b}$. Algoritma Pengurangan mencari hasil pengurangan nilai a dan $b$, dari pengurangan dua bilangan tersebut akan menghasilkan total nilai.

\section{ALGORITMA :}

1. Masukkan nilai a

2. Masukkan nilai $b$

3. Kurangkan nilai a dan nilai b

4. Tampilkan hasil penjumlahan

2) Pseudocode
Pseudo maksudnya tiruan serta code maksudnya kode yang tersambung dengan instruksi yang ditulis dalam bahasa pc (kode bahasa pemrograman). Bila diterjemahkan secara leluasa, hingga pseudocode memiliki makna tiruan dari kode bahasa pemrograman. Pada dasarnya, Pseudocode merupakan sesuatu wujud algorithma memakai kode, ciri, ataupun notasi yang dimaksudkan buat menyederhanakan wujud kalimat manusia. Contoh algoritma dalam wujud pseudocode: (Budiman, 2015)

if the score is 90 or above

grade is an " $A$ "

else

$$
\begin{aligned}
& \text { if the score is } 80 \text { or above } \\
& \text { grade is a " } B \text { " } \\
& \text { else }
\end{aligned}
$$

$$
\begin{aligned}
& \text { if the score is } 70 \text { or above } \\
& \text { grade is a "C" } \\
& \text { else }
\end{aligned}
$$$$
\text { grade is an " } F \text { " }
$$

3) Flowchart

Flowchart (Diagram Alir) adalah skema yang menunjukkan aliran atau urutan untuk menggambarkan suatu proses. Flowchart memiliki fungsi untuk menggambarkan, menyederhanakan suatu proses sehingga mudah dipahami.

Salah satu cara untuk menulis symbol-simbol ini adalah dengan menggunakan flowchart. Flowchart terdiri dari dua jenis yaitu :

1) Flowchart Program 
Bagan alir program merupakan bagan yang menggambarkan alur logika informasi yang hendak diproses dalam program dari dini sampai akhir. Bagan alir program merupakan perlengkapan yang bermanfaat untuk programmer buat mempersiapkan program yang kompleks. Bagan alir terdiri dari simbol-simbol yang mewakili guna langkah-langkah program serta garis alir( flow lines) membuktikan urutan dari simbol yang hendak diproses. (Budiman, 2015)

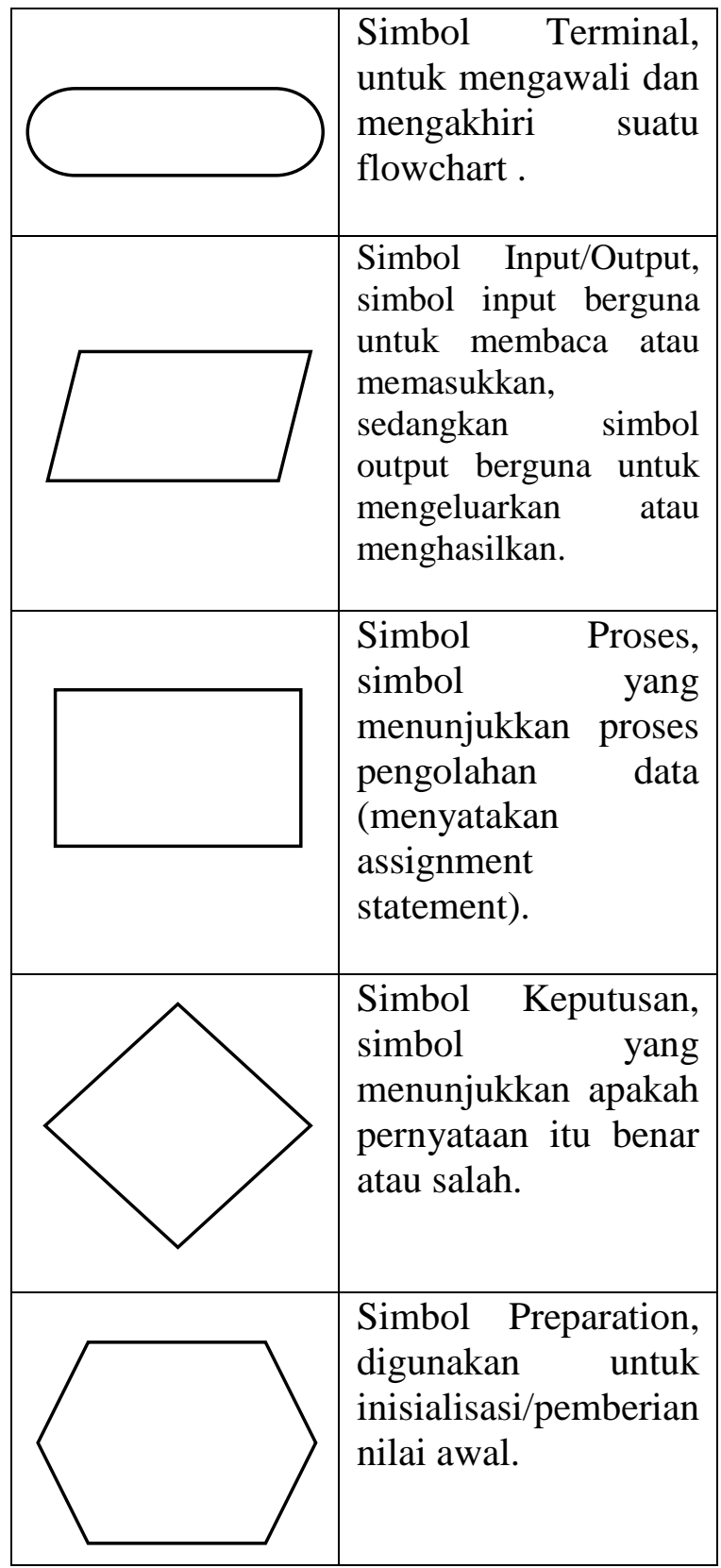

\begin{tabular}{|l|l|}
\hline \multicolumn{1}{|l|}{} & $\begin{array}{l}\text { Simbol proses } \\
\text { terdefinisi, simbol ini } \\
\text { biasa digunakan } \\
\text { untuk proses } \\
\text { menjalankan sub } \\
\text { program. }\end{array}$ \\
\hline$\longrightarrow$ & $\begin{array}{l}\text { Simbol Penghubung } \\
\text { ke halaman lain, } \\
\text { simbol yang } \\
\text { digunakan untuk } \\
\text { menghubungkan } \\
\text { bagian diagram alir } \\
\text { pada halaman yang } \\
\text { berbeda. }\end{array}$ \\
\hline & $\begin{array}{l}\text { Simbol Connector, } \\
\text { biasanya digunakan } \\
\text { sebagi penghubung } \\
\text { bagian algoritma } \\
\text { yang berada dalam } \\
\text { satu halaman. }\end{array}$ \\
\hline $\begin{array}{l}\text { Simbol Arah aliran, } \\
\text { simbol yang pasti } \\
\text { atau wajib ada di } \\
\text { Flowchart untuk } \\
\text { menunjukkan arah } \\
\text { proses. }\end{array}$ \\
\hline
\end{tabular}

Contoh penerapan dari flowchart program : 


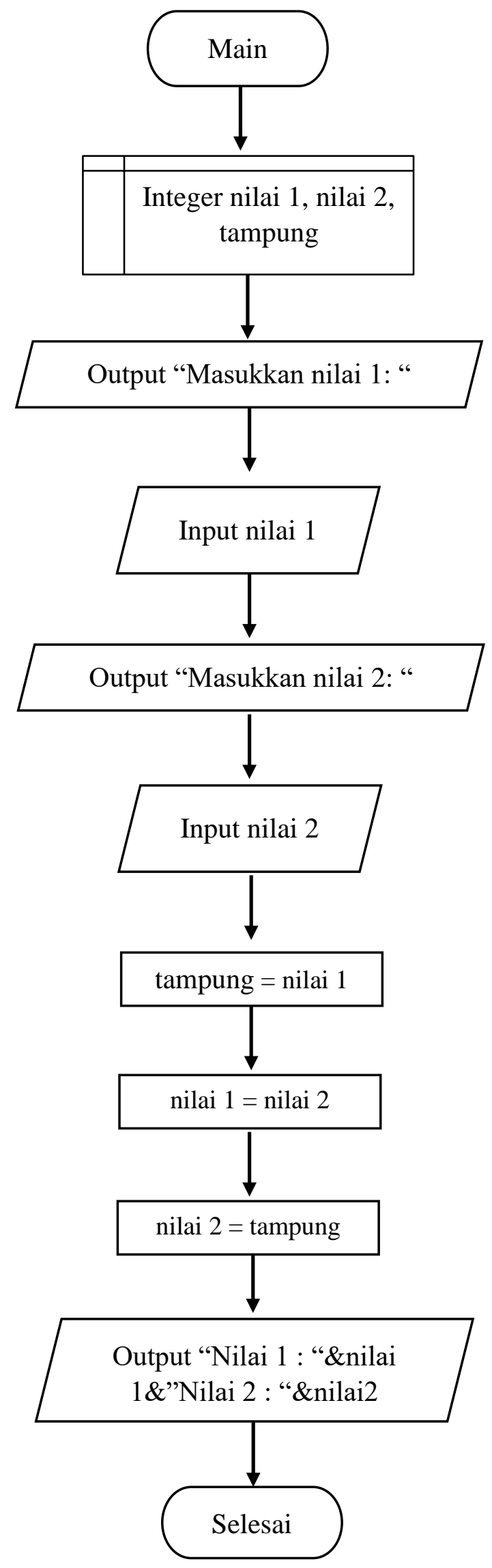

Gambar 1.1. flowchart program menukarkan isi dua buah nilai variable yang diinputkan

2) Flowchart system

Terdapat perbedaan antara bagan alir sistem dengan bagan alir program. Bagan alir program menerangkan secara lebih rinci metode proses dari dini sampai akhir perogram. Bagan alir sistem cuma menggambarkan aliran informasi dari sistem. Simbol yang digunakan pada bagan alir sistem merupakan sama, serta terdapat pula yang berbeda dengan simbol yang digunakan pada bagan alir program. (Budiman, 2015)

\begin{tabular}{|c|c|c|}
\hline & $\begin{array}{l}\text { Simbol } \\
\text { Dokumen }\end{array}$ & $\begin{array}{lr}\text { Simbol yang } \\
\text { menyatakan } \\
\text { input berasal } \\
\text { dari dokumen } \\
\text { dalam bentuk } \\
\text { kertas atau } \\
\text { output dicetak } \\
\text { ke kertas. }\end{array}$ \\
\hline & $\begin{array}{l}\text { Simbol } \\
\text { Manual } \\
\text { Operasi }\end{array}$ & $\begin{array}{l}\text { Simbol yang } \\
\text { mewakili } \\
\text { pekerjaan } \\
\text { manual. }\end{array}$ \\
\hline & $\begin{array}{l}\text { Simbol } \\
\text { Processing }\end{array}$ & $\begin{array}{l}\text { Simbol yang } \\
\text { menunjukkan } \\
\text { pengolahan } \\
\text { yang dilakukan } \\
\text { oleh komputer. }\end{array}$ \\
\hline & $\begin{array}{l}\text { Simbol } \\
\text { Pengurutan }\end{array}$ & $\begin{array}{l}\text { Simbol yang } \\
\text { digunakan untuk } \\
\text { mengurutkan } \\
\text { dokumen di luar } \\
\text { komputer. }\end{array}$ \\
\hline & $\begin{array}{l}\text { Simbol } \\
\text { Offine } \\
\text { Storage }\end{array}$ & $\begin{array}{l}\text { Simbol yang } \\
\text { mewakili file } \\
\text { non-komputer } \\
\text { yang diarsipkan }\end{array}$ \\
\hline
\end{tabular}




\begin{tabular}{|c|c|c|}
\hline & & $\begin{array}{l}\text { dalam urutan } \\
\text { numerik. }\end{array}$ \\
\hline & $\begin{array}{l}\text { Simbol } \\
\text { Offine } \\
\text { Storage }\end{array}$ & $\begin{array}{l}\text { Simbol yang } \\
\text { mewakili file } \\
\text { non-komputer } \\
\text { yang diarsipkan } \\
\text { dalam urutan } \\
\text { abjad. }\end{array}$ \\
\hline & $\begin{array}{l}\text { Simbol } \\
\text { Offine } \\
\text { Storage }\end{array}$ & $\begin{array}{l}\text { Simbol yang } \\
\text { mewakili file } \\
\text { non-komputer } \\
\text { yang disimpan } \\
\text { berdasarkan } \\
\text { tanggal } \\
\text { kronologis. }\end{array}$ \\
\hline & $\begin{array}{l}\text { Simbol } \\
\text { Magnetic } \\
\text { Tape }\end{array}$ & $\begin{array}{l}\text { Simbol yang } \\
\text { menunjukkan } \\
\text { Input Output } \\
\text { dengan } \\
\text { menggunakan } \\
\text { pita magnetic. }\end{array}$ \\
\hline & $\begin{array}{l}\text { Simbol } \\
\text { Magnetic } \\
\text { Drum }\end{array}$ & $\begin{array}{l}\text { Simbol yang } \\
\text { menunjukkan } \\
\text { Input Output } \\
\text { dengan } \\
\text { menggunakan } \\
\text { Drum magnetic. }\end{array}$ \\
\hline & $\begin{array}{l}\text { Simbol } \\
\text { Magnetic } \\
\text { Storage }\end{array}$ & $\begin{array}{l}\text { Simbol yang } \\
\text { menunjukkan } \\
\text { Input Output } \\
\text { dengan } \\
\text { menggunakan } \\
\text { Diskette. }\end{array}$ \\
\hline & $\begin{array}{l}\text { Simbol } \\
\text { Hard Disk } \\
\text { Storage }\end{array}$ & $\begin{array}{l}\text { Simbol yang } \\
\text { menunjukkan } \\
\begin{array}{l}\text { Input Output } \\
\text { dengan }\end{array}\end{array}$ \\
\hline
\end{tabular}

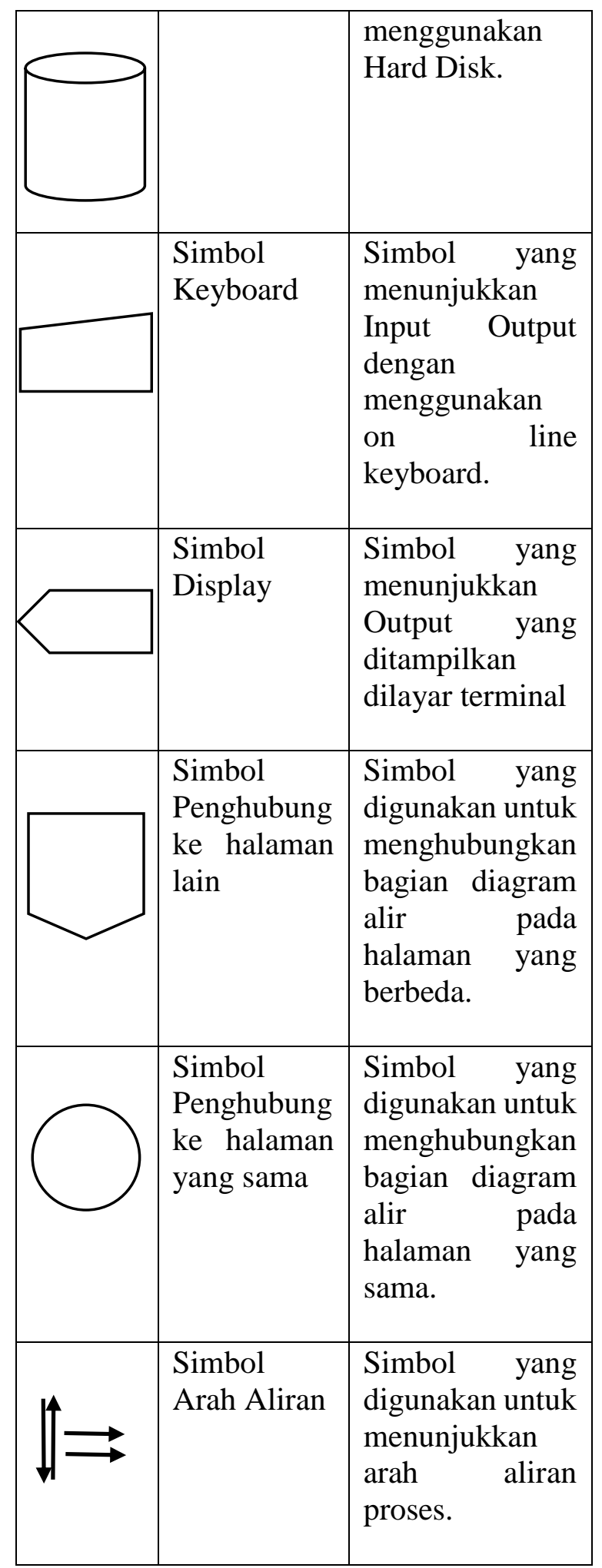

KESIMPULAN 
Algoritma merupakan suatu sebutan yang mengganti ketentuan yang terdapat pada aritmetis yang bermanfaat buat menyelesaikan permasalahan dengan memakai bilangan angka Arab. Program adalah persatuan algoritma dengan bahasa pemroraman (programming language). Program melambangkan metode yang berawal dari suatu algoritma yang berbentuk bahasa pemrograman, kemudian bersedia untuk dipraktikkan dalam mesin yang ada di komputer. Sebaliknya Algoritma Pemrograman merupakan langkah-langkah yang disusun secara tertib buat menuntaskan sesuatu permasalahan pemrograman pc. Sifat-sifat algoritma adalah Input / Masukan, Output / Pengeluaran, Definiteness / Pendefinisan pengguna algoritma. Finiteness / Penyelesaian ,Effectiveness / Efektifitas, Generelity / Umum. Ada 3 struktur bawah pada algoritma ialah runtunan (sequence), pemilihan (selection) serta pengulangan (repetition). Pada dasarnya algoritma dipecah jadi 3 berbagai bersumber pada format penulisannya, ialah : Deskriptif, Pseudocode serta Flowchart. Beberapa fitur dan bagian dari algoritma telah diperiksa. Dengan adanya algoritma pemrograman, hal-hal yang harus diselesaikan dapat dengan mudah diselesaikan dengan bantuan komputer. Dengan mempelajari algoritma pemrograman, orang akan mudah menemukan dan menemukan informasi tentang cara kerja komputer, dan membantu menyelesaikan tugas-tugas berat.

\section{DAFTAR PUSTAKA}

Anggita, Natasya. 2020. "Algoritma dan pemrograman." Jurnal Teknik Informatika,Politeknik Purbaya 5-7.
Ardiansyah, Hendri. Resti Amalia dan Agus Budi Prasetyo. 2019. Algoritma dan pemrograman 1. Banten: Unpam Press.

Budiman, Edy. 2015. Belajar Dasar Algoritma \& Pemrograman. Samarinda.

Fathoni, Saniman dan Muhammad. 2008. "Pengantar Algoritma Dan Pemrograman." Vol. 4 / No. 1 / 124.

Franita, Yesi dan Megita Dwi Pamungkas. 2019. "Pengembangan Modul Algoritma Dan Pemrograman Untuk Mahasiswa Program Studi Pendidikan Matematika Universitas Tidar." Program Studi Pendidikan Matematika FITK Universitas Tidar 96.

Isroqmi, Asnurul. 2017. "Kemampuan Mahasiswa Memahami Logika Pemrograman Komputer Melalui Algoritma." Pendidikan Matematika Universitas PGRI Palembang Volume 2 Nomor 264.

Maulana, Gun Gun. 2017. "Pembelajaran Dasar Algoritma Dan Pemrograman Menggunakan El-Goritma Berbasis Web." Jurnal Teknik Mesin (JTM) : Vol. 062.

Putriyani, Ade. "Artikel ilmiah algoritma dan pemrograman." 2.

Retta, Allen Marga. Asnurul Iqromi dan Tika Dwi Nopriyanti. 2017. "Pengaruh Penerapan Algoritma Terhadap Pembelajaran Pemrograman Komputer." Pendidikan Matematika, Universitas PGRI Palembang 128.

$\begin{array}{rlr}\text { Ritayani. } \quad \text { "Pengantar } & \text { Algoritma } & \text { Dan } \\ \text { Pemrograman." } & \text { Jurusan } & \text { Teknik }\end{array}$


Informatika Fakultas Ilmu Komputer

Universitas Almuslim 72.

Sari, Dewi Yunita. 2020. Algoritma dan Pemrograman Pascal dan $\mathrm{C}++$. Yogyakarta: K-Media.

Syamsudin, Ahmad. 2020. "Analisis Kesalahan Coding Pemrograman Java Pada Matakuliah Algoritma Pemrograman Mahasiswa Tadris Matematiika IAIN Kediri." Jurnal Tadris Matematika, IAIN Kediri. Vol. 2 /No. 2105. 